\title{
THE PRINCIP CULT AND WHAT IT EVOKES IN HUNGARY
}

\begin{abstract}
On the $28^{\text {th }}$ of June, 1914, a consumptive student, Gavrilo Princip, shot and killed prince Franz Ferdinand, the heir to the throne of the Austro-Hungarian Monarchy. The prince's wife Sofia was also killed by a stray bullet. In the century that has passed since the assassination, the memory of Princip and the cult constructed around him has been distorted beyond recognition. As local and international politics were altered, so changed Princip's image. The memory of Princip now evokes strong reactions not only in the South Slav lands, but in Hungary as well. In what follows, we will examine possible sources for the strong reactions evoked by Princip's memory among Hungarians a century after his act.
\end{abstract}

Key words: Gavrilo Princip; collective memory; Yugoslavism; Hungarians; Maurice Halbwachs; A.M. Hocart; Lord Raglan

\section{KULT PRINCIPA I CO ON EWOKUJE NA WĘGRZECH}

Streszczenie

W dniu 28 czerwca 1914 roku chory na gruźlicę student Gavrilo Princip zastrzelił księcia Franciszka Ferdynanda, następcę tronu monarchii austro-węgierskiej. Od zbłąkanej kuli zginęła także żona księcia, Zofia. W okresie stulecia, które minęło od tego zabójstwa, pamięć o Principie i kult zbudowany wokół niego przeobraziły się diametralnie. Wraz z przemianami polity-
ERIC BECKETT WEAVER
Debreceni Egyetem, Debrecen, Hungary
E-mail: weavere@yahoo.com
This work was supported by the author's own resources.
No competing interests have been declared.

This is an Open Access article distributed under the terms of the Creative Commons Attribution 3.0 PL License (creativecommons.org/licenses/by/3.0/pl/), which permits redistribution, commercial and non-commercial, provided that the article is properly cited. (c) The Author(s) 2016.

Publisher: Institute of Slavic Studies, Polish Academy of Sciences [Wydawca: Instytut Slawistyki PAN] 
ki lokalnej i międzynarodowej zmieniało się także postrzeganie Principa. Obecnie pamięć o Principie wywołuje silne reakcje nie tylko na ziemiach południowosłowiańskich, ale również na Węgrzech. Autor artykułu docieka, skąd mogą wypływać silne reakcje, jakie pamięć Principa wywołuje u Węgrów sto lat po jego czynie.

Stowa kl u c zo we: Gavrilo Prinzip; pamięć zbiorowa; Jugoslawizm; Węgrzy; Maurice Halbwachs; A. M. Hocart; Lord Raglan

I $\mathrm{n}$ one of the most evocative passages in a work about collective memory, the French sociologist Maurice Halbwachs notes that our memories of past events change as our mood and personal fortunes change, and that these changes in memory help bring our present condition into harmony with our past, and further to establish harmony with the (also changing) expectations society places upon us: "Society from time to time obligates people"-noted Halbwachs—" not just to reproduce in thought previous events of their lives, but also to touch them up, to shorten them, or to complete them so that, however convinced we are that our memories are exact, we give them prestige that reality did not possess." (Halbwachs, 1992, p. 51)

This line of thought is also familiar to anthropology. Halbwachs' contemporary, the British anthropologist Arthur Maurice Hocart, demonstrated the harmony between social beliefs and rituals, and each society's unique historical narrative. ${ }^{1}$ The aristocratic anthropologist Lord Raglan further developed the theory to discuss the falsity of several popular British historical narratives (such as the Anglo-Saxon origins of the English), and simultaneously how futile it was to demonstrate this falsehood. (Lord Raglan, 1936) These beliefs were accepted as unshakable truths by the English then, for they created a sort of harmony between the present and the past. This is true of similar beliefs today, as well. Since anthropologists began to observe societies in a constant state of change, they have been forced to recognize that social changes have effects on what were hitherto thought to be fixed perceptions and memories of the past. This is equally true of tribal societies and of "modern" societies, such as Hungary.

Let's begin with a few quotes from Hungarian texts of various qualities discussing Princip a century after the start of the First World War:

1. "During the first Balkan War Princip fought as a soldier in the Serbian army." (Hungarian Wikipedia - my emphasis). ${ }^{2}$

2. "Gavilo Princip, the Bosnian Serb terrorist who, by murdering Franz Ferdinand, heir to the Austro-Hungarian throne, played a key role in the outbreak of the First World War, died on 28 April 1918 in the prison at Theresienstadt... The student [Princip] was accepted into the ranks of Young Bosnia during the time he spent in Belgrade." 3 (Tamás, n.d.) of Tradition" (1938), in Hocart (1952).

2 In the original: "Az első-Balkán háborúban [Gavrilo] Princip a szerb hadsereg katonájaként vett részt." - accessed August 2014.

3 “1918. április 28-án halt meg Theresienstadt börtönében Gavrilo Princip boszniai szerb terrorista, aki Ferenc Ferdinánd osztrák-magyar trónörökös meggyilkolásával kulcsszerepet játszott az első világháború kirobbantásában...A diákot [Principet] belgrádi tartózkodása idején az Ifjú Bosznia fogadta soraiba..."
} 
3. "With the assumption to power of the Serbian Progressive Party.... in Belgrade, Princip has clearly been turned into a national hero and freedom fighter who struggled against foreign oppression. President Tomislav Nikolić recently stressed in a statement to the press that Serbia would not allow the falsification of history at the anniversery of the outbreak of the First World War, or that certain foreign circles should try to burden Serbia with the responsibility for the outbreak of the war, or to declare Gavrilo Princip to be 'a terrorist like Bin Laden.' ...

The native of Bosnia, Gavrilo Princip, splits opinion in Bosnia-Herzegovina: while the authorities in the Serbian part prepare to erect a copy of the Belgrade statue to Princip in Eastern Sarajevo, the central government of Bosnia would raise a monument to Franz Ferdinand: they wish to restore the statue erected in the prince's honour in 1917." — (Garai Béla, 2014) ${ }^{4}$

Finally, a quote from an outstanding historian - from the very end of his otherwise useful article on the historical debate over the causes of the First World War:

4. "These days, Serbia has declared a historical 'retrial,' and Emir Kusturica is even directing a film on the hero Gavrilo Princip who stood up to the oppressors. After all, if our terrorist is not a terrorist, but a freedom-fighter, then the same is true of our entire people." (Péter, 2014) ${ }^{5}$

It is not terribly difficult for any historian to examine the truthfullness of the statements above. For example, we can learn a great deal about Princip, the assassin of Sarajevo, from the transcripts of his trial which have been published more or less completely in several langauges over the past century. ${ }^{6}$ Moreover, in 1916 the Austrian psychiatrist Martin Pappenheim was able to interview the imprisoned Princip over a series of months, and published transcripts from these interviews in 1926. (Armstrong, 1927; Pappenheim \& Princip, 1926a, 1926b)

Based on the facts, let's take a look at the first statement highlighted above-the statement is false. At the outbreak of the First Balkan War (when Bulgaria, Serbia, Montenegro and Greece attacked the Ottoman Empire) Gavrilo Princip-like so many of his generation-hopefully anticipated the liberation of Balkan peoples from the Turkish yoke, and like many other South Slav citizens of the Austro-Hungarian Monarchy (Croat, Slovene and Serb alike), Princip slipped across the border into Serbia to volunteer for service in the Serbian army. The young man, however, was rejected by Serbian authorities who found him to be in poor physical condition. Princip never fought in any battle.

In the second quote we find mention of an organization called Young Bosnia (Mlada Bosna). Counter to popular belief, no such organization existed in Gavrilo Princip's time. The name-inspired by Mazzini's Giovane Italia-was used to describe the various informal student groupings in Bosnia filled with Yugoslav ideals who were in contact with similar people in Croatia, Dalmatia, Slovenia (etc.). Moreover, Princip first came in touch with such a group in Sarajevo (and not in Belgrade). ${ }^{7}$

\section{-....}

4 “A szerb haladók pártjának hatalomra kerülésével ... Princip egyértelmúen nemzeti hőssé és az idegen elnyomás ellen harcoló szabadságharcossá avanzsált Belgrádban. Tomislav Nikolic elnök nemrégi sajtónyilatkozatában azt hangoztatta, hogy a világháborús évforduló kapcsán nem fogják megengedni a történelemhamisítást, vagyis azt, hogy egyes külföldi körök Szerbiára hárítsák a felelősséget a háború kirobbantásáért, és hogy Gavrilo Principet „Bin Ladenhoz hasonló terroristának” kiáltsák ki. ... A boszniai születésű Gavrilo Princip megosztja Bosznia-Hercegovinát: miközben a szerb országrész hatóságai arra készülnek, hogy KeletSzarajevóban a belgrádi Princip-szobor hasonmását állítsák fel, a boszniai központi kormány Ferenc Ferdinándnak álítana emléket: az évfordulóra felújítják a meggyilkolt főherceg tiszteletére 1917-ben készült emlékmúvet."

5 “Napjainkban Szerbia jelentett be történelmi 'perújrafelvételt', sőt Emir Kusturica filmjét az elnyomókkal szembeszálló, hős Gavrilo Principről forgatja. Hiszen ha a mi terroristánk nem terrorista, hanem szabadsághős, akkor egész népünk az."

6 In order of publication: Pharos (1918); Bogićević (1954); Dolph Owings (1984).

7 In detail, see: Dedijer (1964, p. 575); for a beautiful overview of Mlada Bosna in Hungarian, see: Bazdulj (2014). On Bosnian youths' Yugoslavism, see: Aleksov (2014). 
I will unravel the third quote below, and will only state here that the heroification of Princip is not a new development, and that recently a statue to Princip was first erected in Republika Srpska, and later-using funding from Bosnian-Serb taxpayers-its copy was erected in Belgrade.

Finally, the most interesting quote-the fourth one-and let us start with the wording: Everyone has the right to refer to Princip's acts according to his or her own moral codes, and yet I believe that the word "terrorist" here is not correct. There is, admittedly, an older definition according to which every political murder committed by an ordinary citizen is an act of terrorism (it's enough to recall acts of the revolutionaries in Tsarist Russia), but this definition is no longer used by most people today. Princip's act certainly does not fit with the understanding of "terrorism" that we use most frequently now. Still, we must admit that during the trial both the prosecutor and Princip himself used the term "terror" to describe his act. Yet Princip killed just two people for political reasons (one-the prince's wife-by mistake). No matter how awful the act was, not every political murder is an act of terrorism. For instance, we do not normally use the word "terrorist" for the murderers of the American President J.F. Kennedy, or of Martin Luther King, Junior. Princip was an assassin (we might also call him a murderer), but he never meant to evoke mass fear (terror), or to kill masses of innocent civilians. To the contrary, Princip carried out a planned assassination against the embodiment of Habsburg rule. Only the unreachable Emperor Franz Josef himself could have been a more perfect target than the heir to the throne.

As I have already mentioned, the Bosnian Serb Gavrilo Princip, who declared himself a Yugoslav, did not just become a hero and symbol recently: he was celebrated as a dreamer and creator of the first Yugoslavia already after the First World War. Princip's self-avowed Yugoslav identity perfectly matched official attempts to unify the South Slav peoples in Royal Yugoslavia. What is more, among Princip's collaborators one finds not only Serbs, but a Bosnian Muslim-Mehmed Mehmedbašić, and a Croat-Ivo Kranjčević. Thus it is no wonder that in Royal Yugoslavia a memorial plaque was raised in Sarajevo, on which the following text in Cyrillic could be read:

In this historical place on St. Vitus Day 15 (28) June 1914 Gavrilo Princip proclaimed freedom. In the original: На овом историјском мјесту Гаврило Принцип навијести слободу на видов-дан 15 (28) јуна 1914.

As has recently been discovered by a talented writer, the plaque was removed from its place and taken to Germany in 1941, to be presented to Hitler as a trophy of war on the occassion of his birthday. (Bazdulj, 2013) But Princip was not just considered a hero in Royal Yugoslavia. Later other plaques stood at the place of the assassination. Princip, the pathetic peasant child and hungry student who dreamt of the unification of South Slavs, and acted in a revolutionary manner to fulfil that dream, fit (in these particulars, at least) very well in the Yugoslav communist pantheon. ${ }^{8}$

After the Second World War, footprints set in concrete were placed where he was supposed to have stood when he carried out the assassination and, to replace a temporary plaque that was deemed unsatisfactory, a white marble tablet with red, cyrillic letters was placed on the wall with the following text:

8 A Marxist history that is still the best recounting of Princip's act in any language is: Dedijer (1966b); Serbian edn. Dedijer (1966a). For more on the development of the Princip cult, see: Markovich (2015). 
From this place on 28 June 1914 Gavrilo Princip, with his shot gave expression to the popular protest against tyranny and the centuries old aspiration of our people for freedom.

In the original: Са овога мјеста 28 јуна 1914 Гаврило Принцип својим пуцњем изрази народни протест против тираније и вјековну тежњу наших народа за слободом.

So, as is apparent, Gavrilo Princip was long celebrated as a hero and as the embodiment of the South Slav state. But neither this plaque, nor its symbolic content could survive the disintegration of Yugoslavia. Practically unnoticed, it was finally destroyed along with his Yugoslav ideal during the seige of Sarajevo (April 1992 - February 1996). At that time Princip and his fellows served the people of Sarajevo in a rather different mannertheir chapel-gravesite near the market was used by the public as a toilet during the seige. (Butcher, 2014, p. xx) Thus the citizens of the beseiged city expressed their opinion about the still-existing state called Yugoslavia which, by this time, consisted solely of Serbia and Montenegro.

After the Wars of Yugoslav succession had ended, a new memorial plaque was dedicated in Sarajevo on which the following text can be read in the local language and in English:

„Sa ovog mjesta 28. juna 1914. godine Gavrilo Princip je izvršio atentat na austrougarskog prestolonasljednika Franca Ferdinanda i njegovu suprugu Sofiju.

From this place on 28 June 1914 Gavrilo Princip assassinated the heir to the Austro-Hungarian throne Franz Ferdinand and his wife Sofia." 9

In contrast to earlier ones, this plaque does not attempt to reveal the reason for the assassination. It is as if the act-one of the events that led to the First World Warnow hung there meaninglessly, inexplicably, and without sense. Yet no matter how much the creators of the text of this new plaque wished to avoid it, Princip's act cannot be left without interpretation. We need-we must-make sense of the background of one of the greatest catastrophes of humanity. Debate on its meaning is ongoing within the countries of the former Yugoslavia, especially within Bosnia, and is even reflected in differences in interpretation in the various (Bosniak, Croat, and Serb) school history textbooks. ${ }^{10}$ These differences in interpretation are not only about who was responsible for the outbreak of the First World War, but on how to evaluate the former Yugoslavia. In communist Yugoslavia, the tyranny of Royal Yugoslavia was freely discussed. Now, after the break-up of Tito's country, the crimes of Yugoslav communists also can be discussed. With revelations of communist crimes, national historians in the various South Slav countries are no longer interested in stressing the outstanding role their people played in building Yugoslavia; quite the opposite, the goal now is to reveal national suffering, and to foist the crimes of both Yugoslavias off onto other nations. ${ }^{11}$ The problem here is not with the crimes committed by the state, but in national responsibilities for a state (and for its disintegration) which (even through oppression garnished with international ideologies) attempted to unify the South Slav peoples. Here, again, a role can be and is given to Princip, even though he never saw the establishment of the Yugoslav state, for he died on 28 April 1918 in prison in excruciating pain from the tuberculosis which was attacking his bones and wasting his body. His death came six months before the Austro-Hungarian Monarchy he so despised also disintegrated. Now he can be described as a Serbian pa-

\section{-......}

9 For another view of the plaques and the Princip cult, see: Katz (2014).

10 See: Džidić et al. (2014).

11 For some examples, see: Subotić (2015). 
triot or nationalist, even as a terrorist (not only in Hungarian, but in a Bosnian Muslim textbook), as a liberator, as an unfortunate madman, and as the dreamer of a lost illusion.

The view of Princip's role has not only changed among South Slavs, but among Hungarians too. The clearly negative tone in which Princip's act is described by various Hungarian authors, and the general use of the term "terrorist" suggests the intensity of emotions involved, even though a century has now passed since the murders he committed, and even though it is obvious to all that Princip did not really cause the First World War, and was in no way responsible for the Trianon Treaty in which Hungary lost two-thirds of its territory after that war (for he was long dead when the treaty was signed). So what is the source of this passion? Murder is indeed repulsive, but there are many murderers in history whom we recall without particular emotion. Morevoer, Princip's idea-that the House of Habsburg was his people's enemy-is not foreign to Hungarians. To quote from the declaration of dethronement ratified by the Hungarian Parliament in Debrecen, Hungary in 1849: "This dynasty... cannot show a single ruler who has dedicated his energy or glory to the freedom of his peoples." 12 Princip's animosity to the Habsburgs clearly cannot be the problem.

And the more closely one looks at Princip's victim Franz Ferdinand, the more strange Hungarians' current antipathy seems. Throughout his life, Franz Ferdinand was a notorious Hungarian-hater. He planned to weaken the Hungarians' role in the dual monarchy, and to eliminate the Ausgleich/agreement between Hungary and Austria. The following passage from a letter to his former teacher gives a good sample of Franz Ferdinand's feelings about Hungarians:

The so-called decent Hungarian simply doesn't exist and every Hungarian, be he a minister, a prince, a cardinal, a tradesman, a peasant, a stable boy or a servant, is a revolutionary and an ass (I exempt the Cardinal from being an ass, but he's a republican). ${ }^{13}$

No wonder, then, that certain leading circles in Budapest received the news of the death of the heir to the throne with satisfaction. ${ }^{14}$ Thus, the outburst among Hungarian authors against the new Princip-cult cannot be explained by sympathy for Franz Ferdinand. ${ }^{15}$

Instead, the source of these emotions is to be found in the disappearance of Yugoslavia. These days it is a generally held belief among Hungarians that Yugoslavia was a false, artificial creation - the deformed child of Trianon and the Versailles system. As long as the country existed-in the form of communist Yugoslavia-and especially when the Croat-Slovene Tito ran it from Belgrade under the slogan of "brotherhood and unity," this idea could not appear convincing. Therefore, the existence of earlier memorials to Princip was not terribly remarkable. The fact that someone had acted as Princip did for Yugoslavia did not arouse much interest. For Hungarians, the Princip-cult, or rather Princip monuments, were just another foreign symbol among many that were in harmony

\section{-.....}

12 From the Dethronement Declaration, read by Szacsvay to Parliament, 19 April 1849, in: Dénes (1870, p. 90).

13 Franz Ferdinand's letter to his former teacher, Max Wladimir von Beck, 28 Aug. 1905, in: Kiszling (1953, p. 83); in English trans. in King and Woolmans (2013, p. 134).

14 See discussion of the assassination in: Galántai (1964).

15 Some may think of nostalgia for the Habsburg period among Hungarians, but though the sentiment does exist, it appears to me to be that of but a small minority. There is not a single monument to Franz Joseph, Hungary's last Habsburg king, in all of Budapest. Moreover, when the historian András Gerő suggested there should be one, his idea was met with indifference, at best, and with derision in some circles. I admit, however, that I could be wrong. I was certainly surprised when a person close to the current government of Hungary declared that his organization "would reform the European Union along the lines of the AustroHungarian Monarchy... According to plans, foreign policy, defense, and the administration of finance would come under common direction." T. Fricz's ideas as reported in Magyar Nemzet, 6 June 2014. There is no sign that the Hungarian government is in the least interested in this idea-to the contrary. 
with the world. As long as Yugoslavia existed, its existence was accepted-as was that of the Soviet Union-and very few could imagine that it would fall apart at some point in the near future. Now that Yugoslavia has finally and permanently fallen to pieces, it is practically impossible to imagine that any sane person would have done anything at all for the Yugoslav idea. The past, in which Princip carried out an assassination for the Yugoslav ideal and paid so dearly for his act, is incompatible with the present. It is apparently easier to believe that Princip murdered for the cause of Serbian nationalism (or patriotism, if you will), than to recall that he believed in Yugoslavism. It is easier to believe that he was a terrorist, and that he committed terror for a nationalism which killed many people in the more recent past. With this, Princip's act falls into a comfortable place, one in agreement with our understanding of the present. To return to Halbwachs' remark: as the memory of Princip changes, the present and the past come into harmony with one another-for some Hungarian authors, this harmony is evoked precisely by despising Princip's entire being, as a terrorist.

Yet despite the fact that everywhere-not just among Hungarians-Princip's memory has been changed to match the present, there are still people who cannot accept these changes. Their very being speaks against this. I am not referring only to those who remember with fondness the former Yugoslavia, but those who, one might say, have the Yugoslav ideal in their blood. Those with a Hungarian (or perhaps Slovene) father, and a Serbian (or Croatian, or Macedonian) mother (etc.). And there are also those Montenegrins, Slovenes (etc.), for whom Belgrade, Sarajevo, and Zagreb will always more familiar and dear than any other foreign city. Though the country and its ideal are dead, the spirit of Yugoslavia still haunts certain people, certain moments, and certain places, and it is surely in these moments and places that Gavrilo Princip's spirit belongs.

\section{BIBLIOGRAPHY}

Aleksov, B. (2014). Forgotten Yugoslavism and anti-clericalism of young Bosnians. Prilozi (Sarajevo), 43, 79-87.

Armstrong, H. F. (Ed.). (1927, August). Dr. Pappenheim's conversations with Princip: Confessions of the assassin whose deed led to the World War. Current History.

Bazdulj, M. (2013, October 31). Srećan rođendan, gospodine Hitler. Vreme, (1191).

Bazdulj, M. (2014). Az Ifjú Bosznia. Pro Minoritate, (Summer), 85-96.

Bogićević, V. (Ed.). (1954). Sarajevski atentat; izvorne stenografske bilješke sa glavne rasprave protiv Gavrila Principa i drugova, održane u Sarajevu 1914 g. Kritička obrada. (V. Bogićević, Trans.). Sarajevo: Državni Arhiva NR BiH.

Butcher, T. (2014). The trigger: Hunting the assassin who brought the world to war. London: Chatto \& Windus.

Dedijer, V. (1964). Sarajevo fifty years after. Foreign Affairs, 42(4), 569-584. http://dx.doi. org/10.2307/20029714

Dedijer, V. (1966a). Sarajevo 1914. Beograd: Prosveta.

Dedijer, V. (1966b). The road to Sarajevo. New York: Simon \& Schuster.

Dénes, P. (1870). A Parlament Debrecenben (Vol. 2). Leipzig: Köhler K.A.

Dolph Owings, W. A. D. (Ed.). (1984). The Sarajevo trial (Vols. 1-2). Chapel Hill, NC: Documentary Publications. 
Džidić et al., D. (2014, May 6). Gavrilo Princip: Hero or villain? The Guardian.

Galántai, J. (1964). Magyarország az Első Világháborúban 1914-1918. Budapest: Gondolat. Garai Béla, J. (2014, January 24). Gavrilo Princip nem volt terrorista. Magyar Hírlap.

Halbwachs, M. (1992). On collective memory. (L. A. Coser, Trans.). Chicago: University of Chicago Press. (Originally published as Les cadres sociaux de la mémoire, Paris: F. Alcan, 1925).

Hocart, A. M. (1952). The life giving myth and other essays. (Lord Raglan, Ed.). London: Methuen \& Co. Ltd.

Katz, V. (2014). Ideological use of memorial plaques dedicated to Gavrilo Princip in the upbringing and education of generations of youth in Bosnia and Herzegovina. Prilozi (Sarajevo), 43, 99-111.

King, G., \& Woolmans, S. (2013). The assassination of the Archduke. London: Macmillan. Kiszling, R. (1953). Franz Ferdinand von Österreich-Este. Graz: Hermann Böhlaus.

Lord Raglan. (1936). The Hero: A study in tradition, myth, and drama. London: Watts \& Co.

Markovich, S. G. (2015). Coping with the memory of Gavrilo Princip in Serbia and the symbolism of Vidovdan in Yugoslavia. The South Slav Journal, 34(1-2), 26-57.

Pappenheim, M., \& Princip, G. (1926a). Gavrilo Princips Bekenntnisse: Ein geschichtlicher Beitrag zur Vorgeschichte des Attentates von Sarajevo; zwei Manuskripte Princips; Aufzeichnungen seines Gefängnispsychiaters Dr. Pappenheim aus Gesprächen von Feber bis Juni 1916 über das Attentat, Princips Leben und seine politischen und sozialen Anschauungen. Wien: Lechner.

Pappenheim, M., \& Princip, G. (1926b). Princip o sebi: Jedan prilog historije sarajevski antentat. Zagreb: Jugoslovenska Štampa.

Péter, B. (2014, May 9). 1914 nyara. Élet és Irodalom, (19).

Pharos. (Eds.). (1918). Der Prozess gegen die Attentäter von Sarajewo, nach dem amtlichen Stenogramm der Gerichtsverhandlung aktenmässig dargestellt von ... (J. Kohler, Introduction). Berlin: R. v. Decker.

Subotić, J. (2015). The mythologizing of communist violence. In L. Stan \& N. Nedelsky (Eds.), Post-communist transitional justice: Lessons from 25 years of experience (pp. 188-209). Cambridge: Cambridge University Press. http://dx.doi.org/10.1017/ CBO9781107588516.014

Tamás, T. M. (n.d.). 1918. április 28. Gavrilo Princip halála. Retrieved 28 April 2016, from http://www.rubicon.hu/magyar/oldalak/1918_aprilis_28_gavrilo_princip_halala/ 